\title{
Analisis Pasal 284 KUHP \\ Tentang Tindak Pidana Zina
}

\author{
M. Aunul Hakim \\ Dosen Fakultas Humaniora dan Budaya Universitas Islam Negeri (UIN) Malang
}

\begin{abstract}
Indonesia is a state that had a Criminal Code named by KUHP. The regulation draft about adultery specially mentioned at paragraph 284. According to this paragraph, the definition of adultery is sexual intercourse conducted by a man/woman who has valid marriage with another woman/man who is not his/her wife/husband and it is conducted based on the wish of each of them. In Criminal Code, it is stated that such deed may be imposed as a crime if there is a plea from the wife/husband who is harmed. Adultery crime is called as offense that warrants complaint, and punishment is 9 months. It's different with the meaning of adultery according to Islamic Law which has meaning a sexual intercourse conducted by a man and woman who are not a valid pair of marriage.
\end{abstract}

Keywords: adultery, plea, punishment

\section{A. Pendahuluan}

Praktekperzinaan sudah dikenal sejak dahulu sampai saat ini di negara manapun di dunia ini. Aturan-aturan yang melarang atau yang mencegah adanya praktek perzinaan telah dibuat oleh negara, agama ataupun adat, namun fenomena perzinaan masih tetap menggejala dan selalu meningkat.

Masyarakat Indonesia merupakan masyarakat yang bersifat kekeluargaan, kolektif. Dalam masyarakat demikian, zina bukanlah suatu perbuatan yang semata-mata bersifat pribadi, melainkan terkait juga dengan kepentingan keluarga, lingkungan dan masyarakat. Bertolak belakang dengan pandangan tersebut adalah pandangan masyarakat barat pada umumnya dan masyarakat Eropa dan Belanda khususnya sebagai negara penjajah yang mana secara tidak langsung memiliki peran besar dalam memproduk Hukum Pidana di Indonesia. Masyarakat barat bersifat 
individualistik-liberalistik, hubungan seks dipandang sebagai hal yang sangat pribadi dan dapat dilakukan dengan apa saja, sepanjang hubungan seks itu dilakukan tanpa adanya paksaan. Dengan demikian merupakan suatu hal yang wajar apabila perbuatan zina tertentu, yang dilakukan oleh mereka yang terikat dalam perkawinan (adultery), ditetapkan sebagai tindak pidana aduan.

Menurut hukum adat dari sebagian besar daerah Indonesia, persetubuhan antara seorang laki-laki dan seorang perempuan di luar nikah, adalah dianggap sebagai suatu perbuatan yang hina, tidak membedakan apakah si pelaku itu sedang punya isteri/suami, ataupun tidak punya isteri/ suami. Anak yang dilahirkan akibat persetubuhan itu disebut "anak haram/ jadah". Ini dapat dipahami, karena masyarakat Indonesia sebagian besar dipengaruhi oleh agama Islam.

Masyarakat Indonesia merupakan masyarakatreligius. Walaupun negara Indonesia bukan negara agama, negara Indonesia tetap sangat memprihatinkan dan selalu berusaha memelihara kehidupan beragama. Di Indonesia terdapat jalinan yang cukup kuat antara negara dan agama. Dengan demikian nilai-nilai agama sangat berpengaruh terhadap perumusan tindak pidana kesusilaan. Dalam hal ini Oemar Seno Aji mengemukakan pandangannya sebagai berikut, dalam menggariskan politik hukum pidana nasional khususnya dalam bidang kesusilaan kita lihat unsur agama untuk mengisi dan mengarahkan delik-delik susila sesuai dengan keinginan kita untuk memancarkan Pancasila dalam segalabidang hukum, termasuk hukum pidana, unsur agama memegang peranan pengisian, jika tidak dikatakan faktor yang memastikan dalam mencari kualifikasi apakah suatu delik itu bersifat susila atau tidak.

Masyarakat Indonesia adalah masyarakat yang beragama, mereka memandang zina adalah salah satu dari perbuatan yang melanggar normanorma agama maupun norma adat, dan negara juga telah mengatur kehidupan rakyatnya dengan berbagai macam undang-undang dan peraturanperaturan demi terciptanya ketertiban dan keamanan masyarakatnya kłıususnya untuk memberantas praktek perzinaan, maka produk hukum pidana di Indonersia dikenal dengan nama Kitab Undang-Undang Hukum Pidana disingkat dengan KUHP. 
Sebagaimana diketahui KUHP itu merupakan produk hukum kolonial Belanda yang banyak dipengaruhi oleh aliran pemikiran modern sekuler. Kitab Undang Undang Hukum Pidana (KUHP) yang berlaku di Indonesia sejak zaman kolonial Belanda sampai sekarang, telah mengatur tentang hukum perzinaan dalam Pasal 284, sedangkan empat pasal berikutnya mengatur tentang hukum persetubuhan yang disertai dengan unsur-unsur lain, sehingga dalam hal ini akan menimbulkan interpretasi yang berbeda dengan pemahaman sebagian besar masyarakat Indonesia tentang tindak pidana zina menurut pasal tersebut.

\section{B. Zina dan dampaknya}

Hubungan seksual pada dasarnya memang kegiatan pribadi, namun istilah "perzinaan" muncul sebagai pencerminan adanya ketidakwajaran dalam aktivitas pribadi. Guna mengukur wajar tidaknya aktivitas seksual, seperangkat nilai yang ada pada relasi seksual dapat dijadikan sebagai parameter, yang antara lain terdiri dari:

1. Nilai prokreasi, bahwa hubungan seksual ditujukan untuk menghasilkan keturunan.

2. Nilairekreasi, yakni kontak seksual merupakan kegiatan memperoleh kesenangan.

3. Nilai keintiman, mengandung makna bahwa intercourse (hubungan seksual) tidak hanya melibatkan unsur badaniah, melainkan mencakup pula unsur batiniah.

4. Nilai legitimasi, bahwa hubungan seksual merupakan bentuk penegasan terhadap keabsahan ikatan perkawinan.

5. Nilai ibadah, yaitu sebagai manifestasi pelaksaan perintah Tuhan tentang pentingnya kasih dan pemeliharaan antara suami dan isteri.(Reza, 1998, 2-3)

Berdasarkan kelima nilai di atas, perzinaan ternyata hanya memenuhi nilai kedua, dan sama sekali tidak mengikutsertakan nilai-nilai lainnya. Kedangkalan seksualitas yang dipraktikkan dengan berpegang hanya pada 
nilai rekreasi ini, dalam pandangan penulis, merefleksikan sebuah gaya hidup hedonistis (anggapan bahwa kesenangan dan kenikmatan hidup adalah tujuan paling utama). Membandingkannya dengan tingkah laku seksual binatang, perzinaan nyata-nyata menunjukkan realitas yang tragis. Alasannya, pada binatang, kontak seksual merupakan sebuah aktivitas dengan orientasi jangka panjang. Sedangkan pada perzinaan, pilihan untuk melakukan intercourse di luar ikatan pernikahan merupakan indikasi bahwa para pelakunya menghindari adanya konsekuensi fisik, psikis, dan sosial

Aib yang ditanggung keluarga para pezina (kerugian sosial), penyakit kelamin akibat sering berganti pasangan dan anak yang lahir maupun digugurkan sebagai akibat perzinaan (kerugian fisik), serta perasaan bersalah dan menyesal (kerugian psikologis), tidak sewajarnya dinafikan begitu saja. Meskipun "hanya" melibatkan pelaku dan keluarga terdekat, ketiga kerugian tersebut merupakan risiko paripuma yang, celakanya, berdampak lebih besar terhadap kaum hawa.

Umumnya agama mengajarkan, bahwa bahwa hubungan sex di luar perkawinan adalah suatu moral yang salah. Bagi seseorang yang beragama dan mengerti akan ajarannya bilamana bertindak melawannya maka ia akan senatiasa merasa bersalah dan menyebabkan ia tersisih dari suatu sumber kekuatan, kedamaian dan kepercayaan yang sangat ia perlukan dalam mengarungi samudra kehidupan.

Remaja yang melakukan zina akan mendatangkan suatu resiko yang sangat besar, yaitu mereka dapat mempunyai keturunan yang mengakibatkan malapetaka baik bagi mereka maupun bagi bayinya, karena mereka belum cukup dewasa untuk menikah dan mendirikan rumah tangga. Anak laki-laki belum siap untuk bekerja untuk membantu isteri dan anak, mereka harus belajar dahulu, dalam keadaan yang tidak memungkinkan karena adanya perkawinan. Mereka belum cukup pandai, pengalaman bagaimana memilih teman hidup atau bagaiman mendirikan rumah tangga. Maka orang tua dan masyarakat akan menetang dan manghukumnya.

Dampak negatif dari perbuatan zina terhadap kesehatan jasmani adalah timbulnya penyakit kelamin, yaitu suatu penyakit yang diawali dengan tumbuhnya gelembung-gelembung bernanah yang menyerang kulit atau alat kelamin penderita. Penyalit ini merupakan penyakit yang berbahaya 
dan menular. Penularan bukan hanya dengan melakukan hubungan seksual saja, melainkan juga dengan bersentuhan melalui kulit, sapu tangan, kain, dan sebagainya. Akibat yang lebih berbahaya lagi dari penyakit kelamin ini adalah bahwa penyakit ini dapat mengakibatkan cacat pada anak yang lahir dari orangtua yang mengidap penyakit tersebut (Ahmad Wardi Muslih, 2005, 5-6).

Penyakit lain yang ditimbulkan oleh perbuatan zina ini adalah penyakit AIDS, yaitu penyakit yang disebabkan oleh virus HIV yang mengakibatkan huilangnya kekebalana (daya tahan) tubuh. Penyakit ini amat ditakuti karena sampai saat ini belum ditemukan obat yang bisa menyembuhkannya.

\section{Hukum Pidana dan sanksinya}

Hukum pidana menurut Prof. Mr. W.F.C. van Hattum seperti tercantum dalam buku Dasar-Dasar Hukum Pidana Indonesia karangan Drs.P.A.F. Lamintang, SH, adalah sebagai berikut:

"het samenstel van de beginselen en regelen, welke de Staat of eenige andere openbare rechtsggemanschap volgt, in zoover hij als handhaver der openbare rechtsorde, onrecht verbiedt en aan zijner voorschriften voor den overtreder een bijzonder leed als straf verbindt"

Yang artinya "suatu keseluruhan dariasas-asas dan peraturan-peraturan yang diikuti oleh negara atau suatu masyarakat hukum umum lainnya, di mana mereka itu sebagai pemelihara dari ketertiban hukum umum lainnya, di mana mereka itu sebagai pemelihara dari ketertiban hukum umum telah melarang dilakukannya tindakan-tindakan yang bersifat melanggar hukum dan telah mengaitkan pelanggaran terhadap peraturan-peraturannya dengan suatu penderitaan yang bersifat khusus berupa hukuman" (Lamintang, 1997, 2-3).

Hukum pidana terbagi menjadi dua, yaitu obyektif dan subyektif. Menurut Prof. Simons, hukum pidana dalam arti obyektif adalah keseluruhan dari larangan-larangan dan keharusan-keharusan, yang atas pelanggarannya oleh negara atau oleh suatu masyarakat hukum umum lainnya telah dikaitkan dengan suatu penderitaan yang bersifat khusus berupa suatu 
hukuman, dan keseluruhan dari peraturan- peraturan di mana syarat-syarat mengenai akibat hukum itu telah diatur serta keseluruhan dari peraturanperaturan yang mengatur maslah penjatuhan dan pelaksanaan dari hukumnya itu sendiri "(Lamintang, 1997, 4).

Adapun dalam arti subyektif, hukum pidana itu mempunyai dua pengertian, yaitu hak dari negara dan alat-alat kekuasaannya untuk menghukum dan hak dari negara untuk mengaitkan pelanggaran terhadap peraturan-peraturannya dengan hukuman.

Dalam sisi lain, hukum pidana dibagi menjadi dua, yaitu hukum pidana material dan hukum pidana formal. Menurut Prof. van Hamel, hukum pidana material itu menunjukkan asas-asas dan peraturan-peraturan yang mengaitkan pelanggaran hukum itu dengan hukuman, sedang hukum pidana formal menunjukkan bentuk-bentuk dan jangka-jangka waktu yang mengikat pemberlakuan hukum pidana material "(Lamintang, 197, 10).

Tindak pidana atau tindakan melawan hukum terbagi menjadi dua, yaitu crimeneel onrecht dan police onrecht. Crimineel onrecht adalah setiap tindakan melawan hukum yang menurut sifatnya adalah bertentangan dengan tertib hukum dalam arti yang lebih luas dari pada sekedar kepentingan-kepentingan, sedangkan policie onrecht adalah setiap tindakan melawan hukum yang menurut sifatnya adalah bertentangan dengan kepentingan-kepentingan yang terdapat di dalam masyarakat.

Dalam hukum positif menurut KUHP ada dua jenis hukuman/pidana, yaitu pidana pokok dan pidana tambahan. Pidana pokok meliputi pidana mati, pidana penjara, pidana kurungan, denda, dan pidana tutupan. Pidana tambahan berupa pencabutan beberapa hak yang tertentu, perampasan beberapa barang yang tertentu, dan pengumuman putusan hakim ( $R$. Sugandhi, 1981, 12).

Pidana mempunyai tujuan-tujuan, yaitu untuk pencegahan (umum dan khusus), perlindungan masyarakat, memelihara solidaritas masyarakat, dan untuk pengimbalan / pengimbangan (Muhari Agus Santoso, 2002, 28).

Efektifitas hukum pidana tidak dapat diukur secara akurat. Hukum hanya merupakan salah satu alat kontrol sosial. Kebiasaan, keyakinan agama, 
dukungan dan pencelaan kelompok, penekanan dari kelompok-kelompok interest dan pengarruh dari pendapat umum merupakan sarana-sarana yang lebih efisien dalam mengukur tingkah laku manusia dari pada sanksi hukum (Barda Nawawi, 1998, 42).

\section{Perzinaan dalam pasal 284 KUHP}

\section{a. Definisi zina}

Zina dalam KUHP dikatagorikan sebagai kejahatan terhadap kesusilaan sebagaimana diatur dalam Buku Kedua Bab XIV pada pasal 284.

KUHP merumuskan delik zina pada pasal 284 yang berbunyi sebagai berikut:

(1) Dipenjara dengan pidana penjara selama-lamanya sembilan bulan: ke-1. a. laki-laki yang beristri yang berzina sedang diketahuinya, bahwa pasal 27 KUH Perdata berlaku baginya;

b. perempuan yang bersuami , yang berzina;

ke-2. a. laki-laki yang turut melakukan perbuatan itu, sedang diketahuinya, bahwa yang turut bersalah itu bersuami;

b. perempuan yang tidak bersuami, yang turut melakukan perbuatan itu,padahal diketahuinya, bahwa yang turut bersalah beristri dan pasal 27 KUH Perdata berlaku bagi yang turut bersalah itu.

(2) Penuntutan hanya dilakukan atas pengaduan suami atau istri yang terhina dan dalam hal bagi suami istri itu berlaku pasal $27 \mathrm{KUH}$ Perdata kalau dalam waktu tiga bulan sesudah pengaduan itu ia memasukkan permintaan untuk bercerai atau hal dibebaskan dari pada kewajiban berdiam serumah oleh karena hal itu juga.

(3) Bagi pengaduan itu tidak berlaku Pasal 72, 73 dan 75.

(4) Pengaduan itu dapat ditarik kembali selama pemeriksaan dalam sidang pengadilan belum dimulai.

(5) Jika bagi laki istri itu berlaku pasal 27 KUH Perdata, maka pengaduan itu tiada diindahkan sebelum perkawinan diputuskan karena 
perceraian atau sebelum keputusan yang membebaskan mereka daripada kewajiban berdiam serumah menjadi tetap."

Zina (overspelt) menurut KUHP adalah persetubuhan yang dilakukan oleh laki-laki atau perempuan yang telah kawin dengan perempuan atau laki-laki yang bukan isteri atau suaminya (R. Sugandhi, 1981, 300).

Menuruthukum, baru dapat dikatakan "persetubuhan", apabila anggota kelamin pria telah masuk ke dalam lubang anggauta kemaluan wanita demikian rupa, sehingga akhirnya mengeluarkan air mani (Lamintang, 1997, 301).

Persetubuhan adalah peraduan antara anggota atau alat kelamin laki-laki dengan perempuan di mana alat kelamin laki-laki harus masuk pada alat kelamin perempuan. Ini mempunyai arti bahwa bukan merupakan persetubuhan manakala alat kelamin laki-laki tidak masuk ke dalam alat kelamin perempuan atau bukan masuk ke dalam alat kelamin perempuan, tapi masuk ke lubang yang lain misalnya mulut atau dubur.

Yang ditunjuk pasal $27 \mathrm{KUH}$ Perdata dalam pasal 1, 2 dan 5 pasal 284 KUHP di atas adalah berbunyi: "Dalam waktu yang sama seorang laki-laki hanya diperbolehkan mempunyai satu orang perempuan sebagai istrinya, seorang perempuan hanya satu orang laki-laki sebagai suaminya" (Subekti, 1995, 8), maka dari sini dapat disimpulkan bahwa perkawinan yang sah menurut KUHP yaitu perkawinan dengan satu istri/suami. Sehingga seorang laki-laki yang memiliki istri lebih dari satu istri, dianggap tidak sah jika belum ada undang-undang yang mengaturnya.

Seseorang yang melakukan hubungan kelamin atau persetubuhan di luar pernikahan atas dasar suka sama suka pada prinsipnya tidak dipidana, kecuali terbukti ada perzinaan (salah satu pihak sudah kawin). Yang dipidana menurut KUHP, hanya apabila persetubuhan di luar nikah itu dilakukan secara paksa (perkosaan), terhadap orang yang pingsan, tidak berdaya atau terhadap anak di bawah umur 15 tahun. 
Hoge Raad berpendapat bahwa mengadakan hubungan kelamin dengan orang lain bukan merupakan zina apabila ada persetujuan dari pihak suami atau istri. Perbuatan itu belum termasuk pelanggaran terhadapkesetiaan perkawinan. Dalam kasus ini seorang lakilaki sebagai calo telah menjadikan istrinya seorang wanita tuna susila, yang dengan demikian membenarkan cara hidup istrinya tanpa syarat apapun (Soerodibroto, 1994, 171).

\section{b. Sanksi tindak pidana zina}

Hampir semua kejahatan hanya dapatdituntutatas pengaduan (permintaan) dari yang kena peristiwa pidana. Peristiwa pidana semacam ini disebut delik aduan.

Sanksi pidana hanya mungkin terhadap perbuatan yang terlebih dahulu ditentukan sebagai dapat dipidana oleh pembentuk Undang-Undang (Schaffmeister dkk, 1995, 26).

Dasar penetapan pidana zina terhadap pelaku tindak pidana zina hanya berdasar atas pengaduan. Dalam teori hukum pidana, dikenal dua jenis tindak pidana aduan yaitu:

(1) Tindak pidana aduan absolut (absolute klach delict)

(2) Tindak pidana aduan relatif (relative klach delict) (R. Sugandhi, 1981, 89).

Tindak pidana aduan relatif artinya, tindak pidana yang sebenarnya adalah tindak pidana biasa (bukan aduan), tetapi dalam hal tertentu dia berubah menjadi tindak pidana aduan. Contohnya, pencurian dalam lingkungan keluarga. Pencurian, sebenarnya bukan tindak pidana aduan. Tetapi kalau pencurian dalam keluarga (pencurian yang dilakukan oleh seorang istri terhadap uang saku suaminya yang tersimpan rapi di kaos kakinya, atau pencurian oleh seorang anak terhadap perhiasan ibu kandungnya), maka pencurian ini termasuk tindak pidana aduan. Tidak akan dilakukan penuntutan oleh pihak berwajib, kecuali ada pengaduan dari keluarganya. 
Berbeda dengan tindak pidana aduan relatif (relative klach delict), tindak pidana aduan absolut (absolute klach delict), dalam keadaan apa pundia adalah tindak pidana aduan. Tidak dapat dituntut kecuali ada pengaduan dari pihak yang berhak menurut hukum yang berlaku. Menurut Wayan P. Windia (dosen Hukum Adat pada Fakultas Hukum Unud), karena zina adalah tindak pidana aduan absolut (absolute klach delict), maka dalam hal ini, walaupun pasangan yang sedang dimabuk cinta menampakkan semangat bercinta menyala-nyala dan terang-terangan, baik dilakukan dalam lingkungan keluarga, dengan tetangga, dengan "dakocan" (dagang kopi cantik), dengan teman sekantor atau atasan langsung dalam satu lembaga pemerintah, tidak dapat dituntut oleh pihak berwajib, tanpa ada pengaduan dari pihak yang berhak mengadukan menurut hukum yang berlaku. Pihak yang dianggap paling berhak mengadukan adalah suami, bagi seorang istri yang berselingkuh, atau seorang istri bagi suami yang berselingkuh. Oknum Hansip dan Kamtib, mertua dan ipar, keluarga dekat dan keluarga jauh, apalagi tetangga, tidak berhak mengadukan sebuah "proyek perselingkuhan", dengan maksud agar perbuatan itu dituntut menurut hukum.

Pengaduan yang dimaksud dalam pasal di atas tidak boleh dibelah menurut $R$. Soesilo, maksudnya apabila laki-laki (A) mengadukan bahwa istrinya (B) telah berzina dengan laki-laki (C), maka $B$ (sebagai yang melakukan perzinaan dan $C$ sebagai yang turut melakukan perzinaan, kedua-duanya harus dituntut ( $R$. Soesilo, 1995, 209). Tidak mungkin misalnya A minta supaya yang dituntut hanya Csaja, tetapi hal ini tidak mengurangkan bahwa jaksa Penuntut Umum berdasarkan atas alasan oportunitet sesungguhnya berkuasa untuk tidak melakukan penuntutan terhadap perempuan tersebut.

Dalam KUHP, pengaduan bisa dicabut sebelum pemeriksaan di muka sidang pengadilan, adapun Hukum Islam pencabutan/ pembatalan bisa terjadi sampai pada proses eksekusi khusus jika dasar . penghukuman adalah pengakuan. 
Sanksi yang diberikan kepada seseorang yang telah terbukti melakukan tindak pidana zina menurut pasal di atas yaitu pidana penjara, yaitu dihukum dengan hukuman penjara selama-lamanya sembilan bulan. Ini adalah lama hukuman yang sangat pendek, bahkan dengan kata-kata selama-lamanya sembilan bulan bisa berarti hukuman bisa berkurang dari sembilan bulan menurut keputusan hakim.

\section{E. Analisis pasal 284 KUHP dari kacamata Hukum Islam}

Setelah dikemukakan di atas tentang penjabaran dari pasal 284 KUHP tentang perzinaan, maka dapat disimpulkan sebagai berikut:

Definisi zina menurut KUHP memberikan kesimpulan bahwa kategori zina adalah terbatas pada hubungan seksual yang dilakukan oleh pria dan wanita yang salah satu atau keduanya terikat hubungan perkawinan, jika dua pelaku persetubuhan itu sama-sama tidak memiliki ikatan pernikahan dengan orang lain tidak dijerat dalam pasal ini, dan mafhum mukhalafah dari makna zina dalam pasal 284 KUHP bahwa siapapun yang melakukan persetubuhan antara laki-laki dan perempuan yang bukan istri/suami yang sah yang dilakukan dengan suka sama suka tidak temasuk orang yang melakukan pidana zina.

Syamsul Huda menyimpulkan bahwa berdasarkan ketentuan demikian, maka menurut KUHP tidaklah merupakan tindak pidana dalam halhal sebagai berikut (Syamsul Huda, 2001,18):

a. Dua orang belum kawin yang melakukan persetubuhan, walaupun:

- perbuatan itu dipandang bertentangan dengan atau mengganggu perasaan moral masyarakat

- wanita itu mau melakukan persetubuhan karena tipu muslihat atau janji akan dinikahi, tetapi diingkari

- berakibat hamilnya wanita itu dan si laki-laki tidak bersedia menikahinya atau ada halangan untuk nikah menurut undangundang. 
b. Seorang laki-laki telah beristri menghamili seorang gadis (berarti telah melakukan perzinahan), tetapi istrinya tidak membuat pengaduan untuk menuntut.

c. Seseorang melakukan hidup bersama dengan orang lain sebagai suami isteri di luar perkawinan, padahal perbuatan itu tercela dan bertentangan dengan atau mengganggu perasaan kesusilaan/moral masyarakat setempat.

Hukum Islam memandang setiap hubungan seksual di luar nikah sebagai zina, baik pelakunya sudah kawin atau belum. Definisi yang lebih lengkap diberikan oleh Mazhab Hanafi, yaitu hubungan seksual yang harars pada kelamin perempuan yang hidup dan menimbulkan syahwat dalam keadaan sadar dan tidak terpaksa di negeri yang adil, yang memberlakukan hukum-hukum Islam, (terhadap perempuan) yang terlepas dari kepemilikan yang benar/sah dan pernikahan yang benar/sah, terlepas dari syubhat akan kepemilikan dan akad pernikahannya, terlepas pula dari syubhat keraguan dalam kepemilikan dan pernikahan (Wahbah Zuhaili, 2004, 5349).

KUHP mencerminkan kepentingan individu keluarga itu lebih penting dari pada kepentingan masyarakat umum, sementara Hukum Islam mementingkan kepentingan masyarakat umum yang di dalamnya juga untuk kepentingan individu keluarga.

Menurut KUHP, tindak pidana zina adalah termasuk tindak pidana aduan absolut (absolute klach delict) yang artinya tidak dapat dituntut kecuali ada pengaduan dari pihak yang berhak menurut hukum yang berlaku dan dalam hal ini pihak yang dirugikan yaitu istri atau suami. Jika si suami atau si istri tidak mengadukan suami/ istrinya, maka tidak berlaku baginya pasal $284 \mathrm{KUHP}$.

Apabila melihat pada KUHP pasal 1 ayat 1 menyebutkan bahwa "Tiada suatu perbuatan yang dapat dipidana kecuali atas kekuatan aturan pidana dalam perundang-undangan yang telah ada, sebelum perbuatan dilakukan", asas legalitas yang dianut di negeri ini sangat ironis, yang sama maknanya dengan pasal 14 ayat 2 UUDS 1950 yang menyebutkan, "Tiada seorang juapun boleh dituntut untuk dihukum atau dijatuhi hukuman,kecuali karena suatu aturan hukum 
yang sudah ada dan berlaku terhadapnya (Supomo, 1954, 33). Maka dapat disimpulkan bahwa perbuatan zina yang dilakukan orang-orang yang tidak termasuk dalam rumusan KUHP tidak dapat dipidana sebelum ada hukum yang mengatur, sehingga pasal ini sangat longgar untuk dapat menjaring perbuatan tindak pidanazina karena hanya mendasarkan pada pengaduan suami atau istri saja jika merasa dirugikan.

Di dalam Hukum Islam, indikator-indikator untuk menetapkan perbuatan tindak pidana zina lebih luas, Hukum Islam menyatakan bahwa penetapan pidana zina bagi seseorang diputuskan untuk diberi sanksi sebagai pelaku zina jika ada salah satu dari tiga hal, yang bersangkutan mengaku atas perbuatannya berzina, adanya empat saksi yang menyaksian perzinaan itu, atau qarinah berupa tanda kehamilan pada seorang wanita yang tidak bersuami.

Delik zina dalam Hukum Islam adalah delik biasa, bukan delik aduan, yaitu diproses melalui hukum jika ada pengakuan, empat saksi atau tanda kehamilan. Dan jika diketahui ada pelanggaran hukum, aparat penegak hukum dapat menyelidiki dan memprosesnya sesuai dengan hukum yang berlaku.

Masalah sanksi atau hukuman bagi pelaku tindak pidana zina, KUHP memberikan hukuman penjara selama-lamanya sembilan bulan, dan hukuman itu tidak membedakan berat dan ringannya hukuman antara yang berstatus kawin dengan yang tidak berstatus kawin. Hal ini sangat berbeda jauh dengan Norma Hukum Islam yang memberi makna zina sebagai hubungan seksual yang dilakukan oleh orang laki-laki dan perempuan yang bukan merupakan suami istri yang sah dan tidak mengandung syubhat. Dan zina ini merupakan tindak pidana kejahatan (jarimatul hudud) yang ancaman hukumannya bagi yang sudah kawin (muhshan) dirajam (dilempari batu) sampai meninggal dunia, adapun bagi yang belum kawin (ghairu muhshan) dijilid (didera) seratus kali dan diasingkan satu tahun.

Pasal 140 ayat 2 KUHAP menyatakan "Dalam hal penuntut umum memutuskan untuk menghentikan penuntutan karena tidak 
terdapat bukti atau peristiwa tersebut ternyata bukan merupakan tindak pidana atau perkara ditutup demi hukum, penuntut umum menuangkan hal tersebut dalam surat ketetapan (KUHAP, tt, 61).

Dengan melihat pada pasal 140 KUHAP, Jaksa Penuntut Umum memiliki hak opportuniteit yaitu menyampingkan dan mendeponeer perkara yang sudah terang pembuktiannya dengan tujuan kepentingan negara atau umum. Sehingga bisa jadi salah satu pelaku zina tidak dihukum atas dasar hak opportuniteit ini. Hak oportuniteit in sangat bertentangan dengan jargon penegakan supermasi hukum "equality before the law" yang memandang semua orang sama di hadapan hukum.

\section{F. Penutup}

Dari fenomena seperti di atas ini jelas-jelas memberikan petunjuk bahwa konsep zina yang ditawarkan oleh KUHP tidak lagi sesuai dengan kondisi masyarakat Indonesia. Karena sebenarnya perbuatan seksual yang dilakukan oleh dua orang yang berlainan jenis tanpa hubungan perkawinan termasuk zina. Selain itu sanksi yang diberikan oleh KUHP kurang memberi hukuman yang setimpal atas perbuatan asusila itu (pasal-pasal yang berkaitan dengan tindak pidana kesusilaan).

Penyusunan KUHP, khususnya yang berkaitan dengan kesusilaan yang tidak dilandasi oleh pemikiran yang bersumber kepada norma agama, dan hanya didasarkan pada pertimbangan rasio semata, pada waktu yang lain dianggap tidak lagi melanggar kesusilaan, dan bahkan dianggap wajar saja. Menurut teori hukum modern yang dinyatakan oleh Jerome Frank, tujuan utama penganut realisme hukum (legal realism) adalah untuk membuat hukum lebih responsif terhadap kebutuhan sosial (Philippe Nonet dan Selznick, 2003, 59), maka seharusnya dalam menyusun KUHP baru memperhatikan kebutuhan sosial masyarakat Indonesia yang mayoritas penduduknya beragama Islam.

Kenyataan-kenyataan tersebut merupakan realita yang dapat memperkuat upaya dilakukannya kriminalitas perbuatan zina dalam arti luas, meliputi sebuah bentuk persetubuhan yang dilakukan di luar perkawinan. 
Kalau kriminalisasi demikian disetujui maka persetubuhan yang dilakukan di luar perkawinan oleh mereka yang sama-sama tidak terikat dalam perkawinan tertentu (fornication) harus dinyatakan sebagai tindak pidana dan merupakan standar delik zina.

Semoga dalam merumuskan hukum pidana baru di Indonesia khususnya tentang delik zina di masa yang akan datang sangat memperhatikan norma-norma agama dan hukum adat yang menjunjung tinggi moral. 


\section{DAFTAR PUSTAKA}

Ahmad Wardi Muslich, 2005. Hukum Pidana Islam, Jakarta, Sinar Grafika.

Barda Nawawi, 1998. Beberapa Aspek Kebijakan Penegakan dan Pengembangan Hukum Pidana, Bandung, PT Citra Aditya Bakti.

Lamintang, 1997. Dasar-Dasar Hukum Pidana Indonesia, Bandung, PT Citra Aditya Bakti.

Muhari Agus Santoso., 2002. Paradigma Baru Hukum Pidana, Yogyakarta, Averrooes Press.

Philippe Nonet dan Selznick, 2003. Hukum Responsif Pilihan di Masa Transisi, Jakarta, (HuMa).

Reza, 1998. Perzinaan dan aspek-aspeknya.

R.Soesilo, 1995. Kitab Undang-Undang Hukum Pidana (KUHP), Bogor, Politea.

R. Sugandi,R., 1981. KUHP dan Penjelasannya, Surabaya, Usaha Nasional. Surabaya, Karya Anda, t.t.,

Schaffmeister dkk., 1995. Hukum Pidana, Yogyakarta, Liberti.

Soerodibroto, 1994. KUHP dan KUHAP, Jakarta, PT Raja Grafindo Persada. Supomo,1954. Undang-Undang Dasar Sementara Rrepublik Indonesia, Jakarta, Noordhoff-Kolff N.V.

Syamsul Huda, 2001. Pernikiran tentang Tindak Pidana Zina Menurut Syariat Islam dalam Rangka Pembaharuan Hukum Pidana Nasiona, Malang. Wahbah Zuhaili, 2004. Al-Fiqhu Al-Islami wa Adillatuhu, Darul Fikri, Damaskus. 